\title{
História da alimentação no Brasil contemporâneo
}

\section{Food history in contemporary Brazil}

\section{Henrique Soares Carneiro ${ }^{1}$}

A apresentação irá resumir a trajetória recente dos estudos sobre alimentação no Brasil e, especialmente, no âmbito das pesquisas realizadas pelo Laboratório de Estudos Históricos das Drogas e da Alimentação. Também serão destacadas as questões alimentares diante dos impasses da crise do modelo econômico global em seus impactos socioambientais.

Palavras-chave: História da Alimentação; História das Drogas; crise do modelo econômico global.

\footnotetext{
1 Professor Doutor de História Moderna do Departamento de História da Faculdade de Filosofia, Letras e Ciências Humanas da Universidade de São Paulo. Fundador e coordenador do Laboratório de Estudos Históricos das Drogas e da Alimentação (LEHDA-USP) e coordenador do II Simpósio Internacional de Pesquisa em Alimentação. No simpósio, também participou da mesa-redonda "Interdisciplinaridade na pesquisa em alimentação".
} 